\title{
CORAL RESEARCH IN THE INDONESIAN ARCHIPELAGO, THE PAST, THE PRESENT, AND THE FUTURE
}

\author{
by \\ MAYA WIJSMAN - BEST ${ }^{1)}$
}

\begin{abstract}
In the past, several big expeditions crossed the Indonesian waters. Coral reefs and their amazing structures and inhabitants were always amongst their special interest. Geomorphological reef theories concerning the Sunda shelf in the Pleistocene period and the barrier reefs in the archipelago have been formulated during the first forty years of the present century.

Two major areas of research are discussed i.e. the Bay of Jakarta with emphasis on structure and history of one of two coral islands, Nyamuk and Sakit, and the Togian area in Celebes. The rich tertiary coral reefs, east of the Pleistocene Sunda shelf around Celebes, are treated at the hand of the studies of the geologist, J.H.F. UMBGROVE. This author came across several coral reef problems which are still of present day interest e.g. the diversity and variability of the coral species as a result of the complex ecosystem.

Two examples are mentioned to give a general idea of the questions arising in different coral species. Nowadays these problems are normally approached from the geological, physiological, ecological or taxonomic point of view. Even so, in the future many field descriptions will have to be carried out along with zoogeographical work in the main centres of taxonomy, before the species of major influence on the structure of the coral reefs can even merely'be listed.
\end{abstract}

\section{INTRODUCTION}

In the last two centuries a few big European expeditions, organized to explore and to understand more of the life and factors of the great oceans, have crossed the Indo-Pacific. Some French and English expeditions during the 19th century, a few Dutch and Belgium in the 20th century. It is not surprising that from the time when Indo-Pacific Ocean was so unexplored until technology and science in the western world had advanced so much as to organize those big expeditions, all kinds of research (enthnological, oceanographical, geological, biological etc.) were carried out. Publications on the results of the expedition (based on data and material collected during these expeditions) still continue to appear.

Because Indonesia is one of the richest coral reef area of the world, as amply discussed in MolengRAAFF (1930) (Fig. 1), and because a lot of research has been carried out by the Dutch, I think it is appropriate that I give a more or less historical review of coral research as it has been carried out in these waters.

1) Rijksmuseum Van Natuurlijke Historic, Leiden, Netherlands. 
MAYA WIJSMAN-BEST

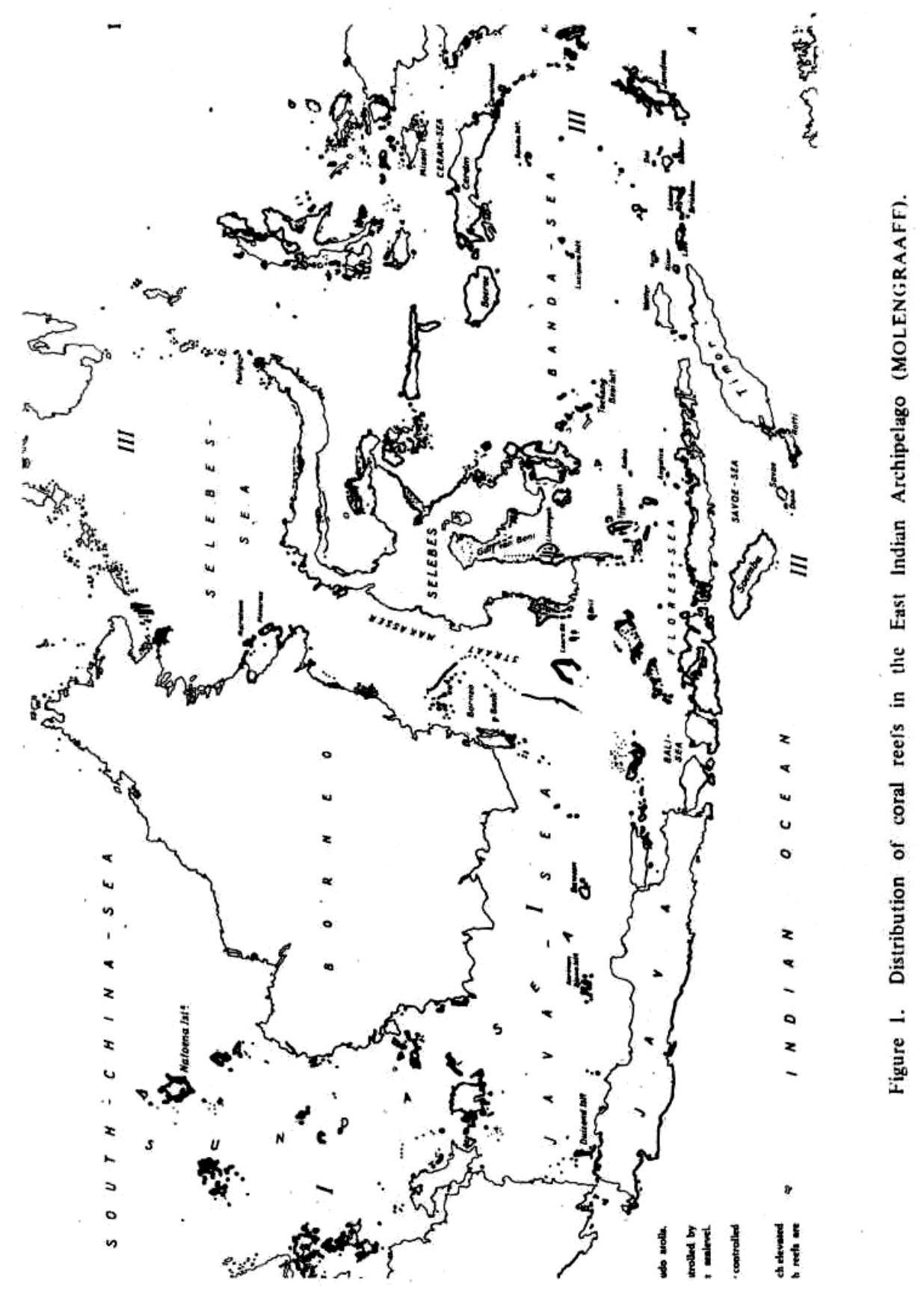


CORAL RESEARCH IN THE INDONESIAN ARCHIPELAGO

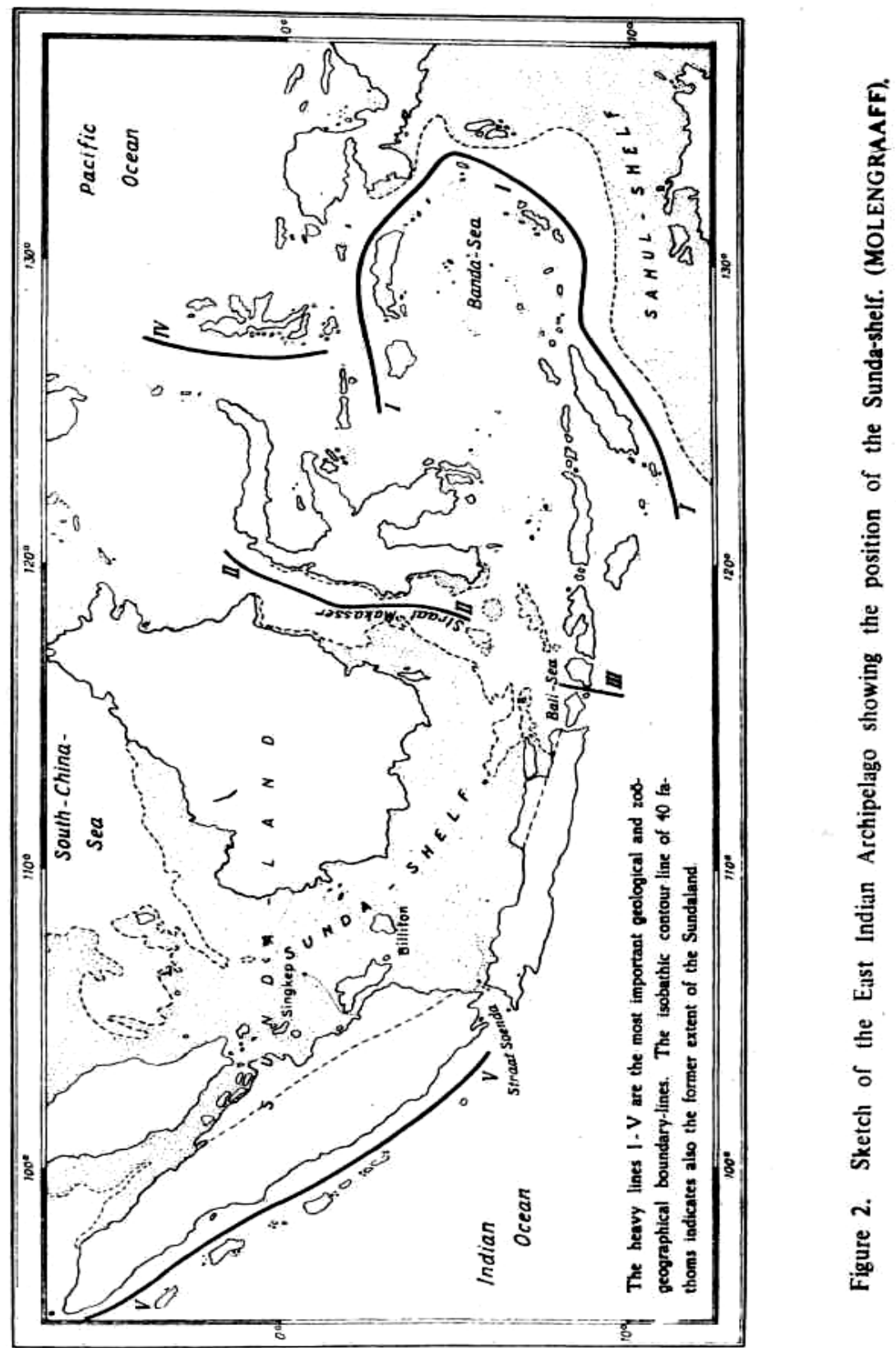




\section{MAYA WiJSMAN-BEST}

It was in Cocos Keeling that DARWIN did his observations and based his theories of the descending ocean floor in 1842. Later on the theories of DALY (1910-1915), the so called "glacial control theories", tried to explain the large oceanflats. By the different ocean levels during the Pleistocene period, coral reefs developed on these large oceanflats and formed, by its growth, the different reefs present nowadays on the various continental shelfs. The strange shelfs or continental flats found in the Indonesian Archipelago, such as the Java Sea and the Sahul Bank, give support to the DALY theories.

The average depth of the Java Sea (=the Pleistocene "South Sunda land") is $50-60 \mathrm{~m}$, so it became dry in the Pleistocene period. The same holds for the Karimata Strait (the Pleistocene "North Sunda land") which has an average depth of 40-45 m. The Pleistocene river system made the sea floor of Karimata Strait and the Java Sea to consist of river mud. All scarce coral reef formation in this area, which is as a whole not very rich because of the high salt percentage and the amount of mud, was

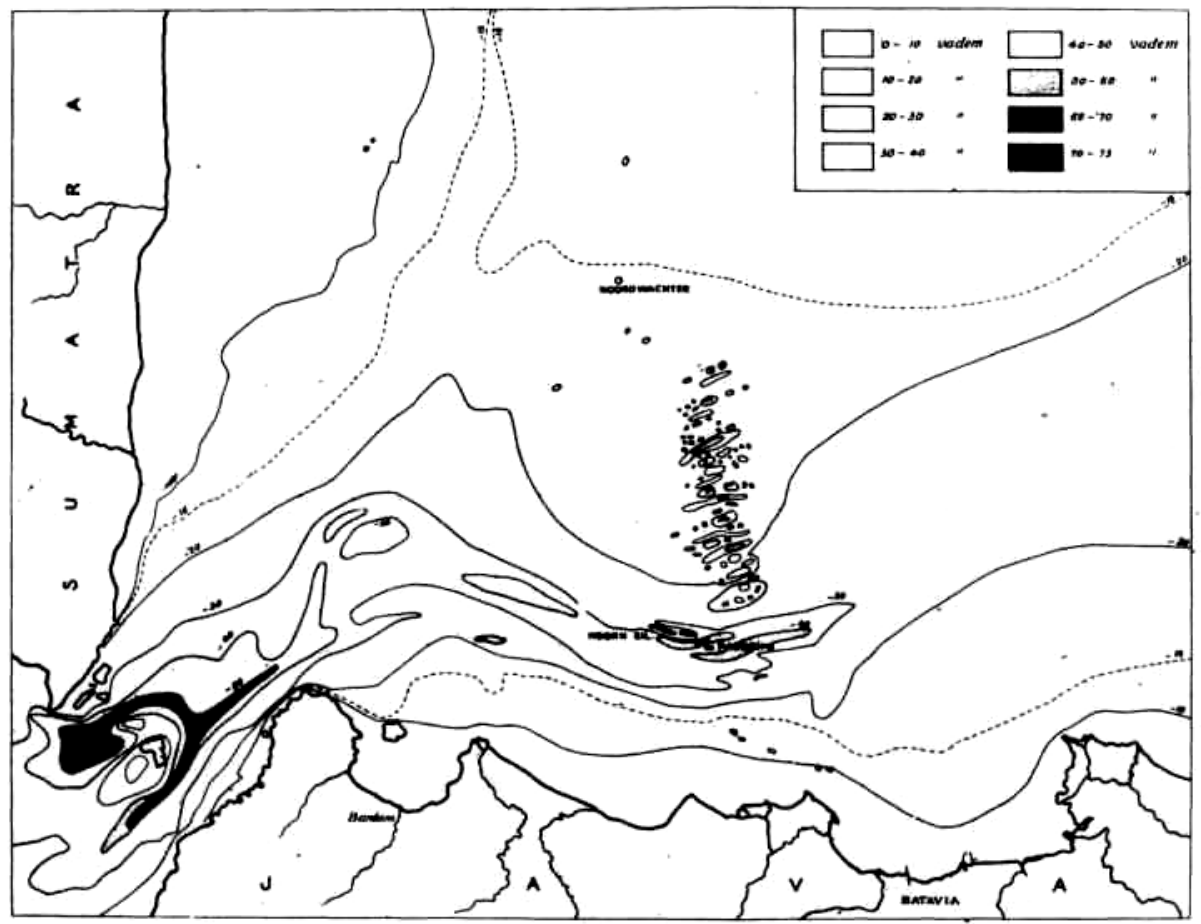

Figure 3. Straits Sunda and the Thousand Island reefs. (UMBGROVE) 
therefore, formed at the end of the Pleistocene period. It is different, of course, with the conditions for coral reef formation at the margins of the Sunda land (Fig. 2). Optimal conditions were present at the east coast of Borneo, bordering the deep Strait of Makassar, where barrier reefs rise up from more than $80 \mathrm{~m}$ depth. The geologist, NiERMEYER, first called this, the Sunda land barrier reef. Less favourable were the conditions in the northern part of the Sunda land, at the border of the South China Sea, which is probably due to the detritus of the large "North Sunda river". Finally the theory of MOLENGRAAFF (1930) calls for a bay in the southern part of the Sunda land around Sunda Strait, in which the rich Thousand Islands reefs developed (Fig. 3).

The barrier reef of West Sulawesi is developed on the Spermonde shelf, formed in the Miocene period. Behind the barrier reef, three rows of coral reef, as well as a fringing reef have been formed (example of the socalled "multiple barrier reef" (Fig. 4).

This short review of the general reef theories, shows how the different coral reefs in the Indonesian Archipelago are excellent examples of fringing reefs that developed to barrier reefs, not as a result of the descending of the ocean floor, but of a rising of the sea level.

\section{HISTORICAL REEF STUDIES}

Apart from those decending and rising of the sea level, the influences of wind and water action are responsible for the different coral reef forms in the Indonesian Archipelago. A good example is the only atoll group DARWIN himself explored (Fig. 5). Cocos Keeling is a half-atoll, the form of which is not a result of descending of a land, but of the constantly prevailing south eastern winds, because the island lies to the south of the monsoon area. Other examples, more closely situated to the equator, are the islands in the Bay of Jakarta.

UMBGROVE (1928) has made a special study of these islands. Nyamuk Island (Fig. 6) will be taken as an example. The beach of the south west side is composed of loose, fine material, which is called coral sand. Towards the north more coarse material is found. This material is called coral shingle and in places, it has been heaped up into high ramparts. These debris are piled up by the wind and the breakers. The mode of distribution of these walls shows the direction where the wind is strongest. The greatest influence of the wind is from the north, the directions (we are here close to the equator) of most coral reef forms and situations in this bay can be explained as a result of wind and water action. Sakit Island (Fig. 7) also shows only coral sand in the south-west corner and a rich reef formation around a lagoon to the north-east of the island. 


\section{MAYA WIJSMAN-BEST}

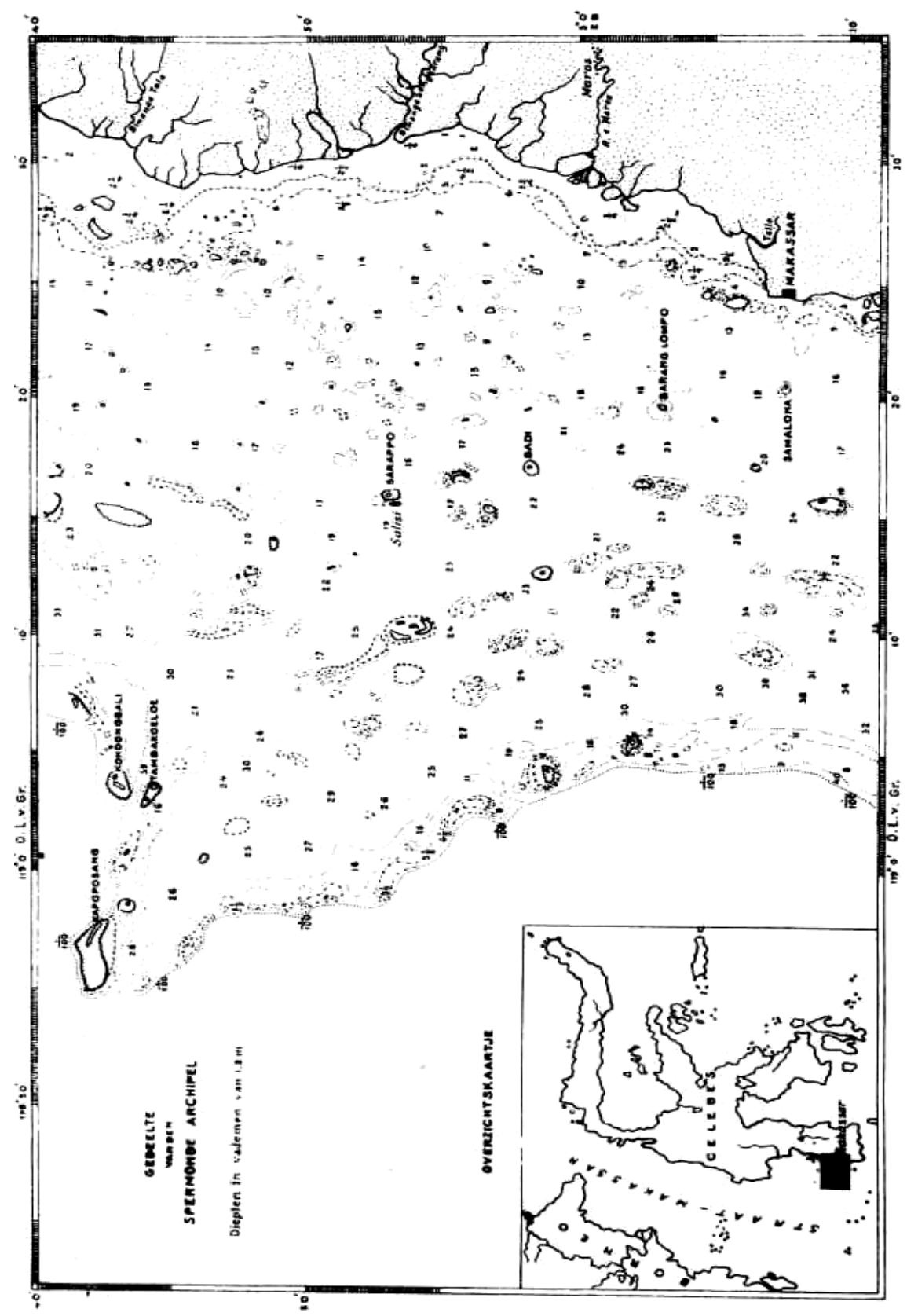

Figure 4. Part of the Spermonde Archipelago (UMBGROVE) 
CORAL RESEARCH IN THE INDONESIAN ARCHIPELAGO

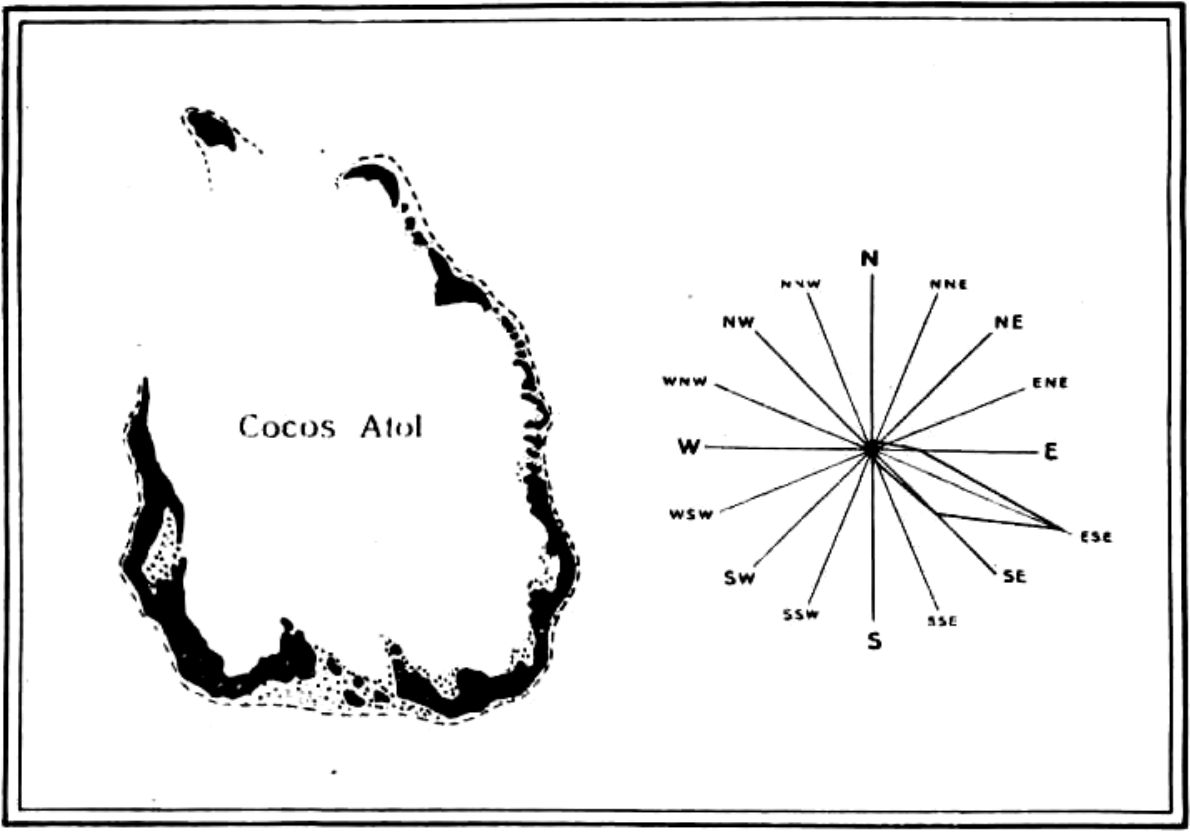

Figure 5. Cocos Atoll (UMBGROVE)

Because of the highly variable ecological conditions on the various places around the island, UMBGROVE distinguishes the different "facies" in describing the general reef-ecology and later on also in treating the intraspecific variability in the different coral species. The reefs around the islands in the Bay of Jakarta and even more the older reefs around the Thousand Islands (Pulau Seribu) lent themselves very well for intraspecific variability studies of corals.

In the last island group, we find the influence of the strong changing currents in the Java Sea i.e. the cold western current (around February) as a result of the western trade wind and the less strong and warmer eastern current (around August) as a result of the eastern trade wind. VERWEY (1931) carried out his coral physiological studies here. Boschma (1948) did some small studies on Scleractinean corals, and started his large Millepore study.

Another area of research in the Indonesian Archipelago is the Togian Islands, Gulf of Tomini, North Sulawesi. The area is protected from wind influences, by the northern and eastern "arms" of Sulawesi. Because of this lack of wind and water action, shingle ramparts are completely lacking, and also the different coral facies as described from the Bay of Jakarta. 


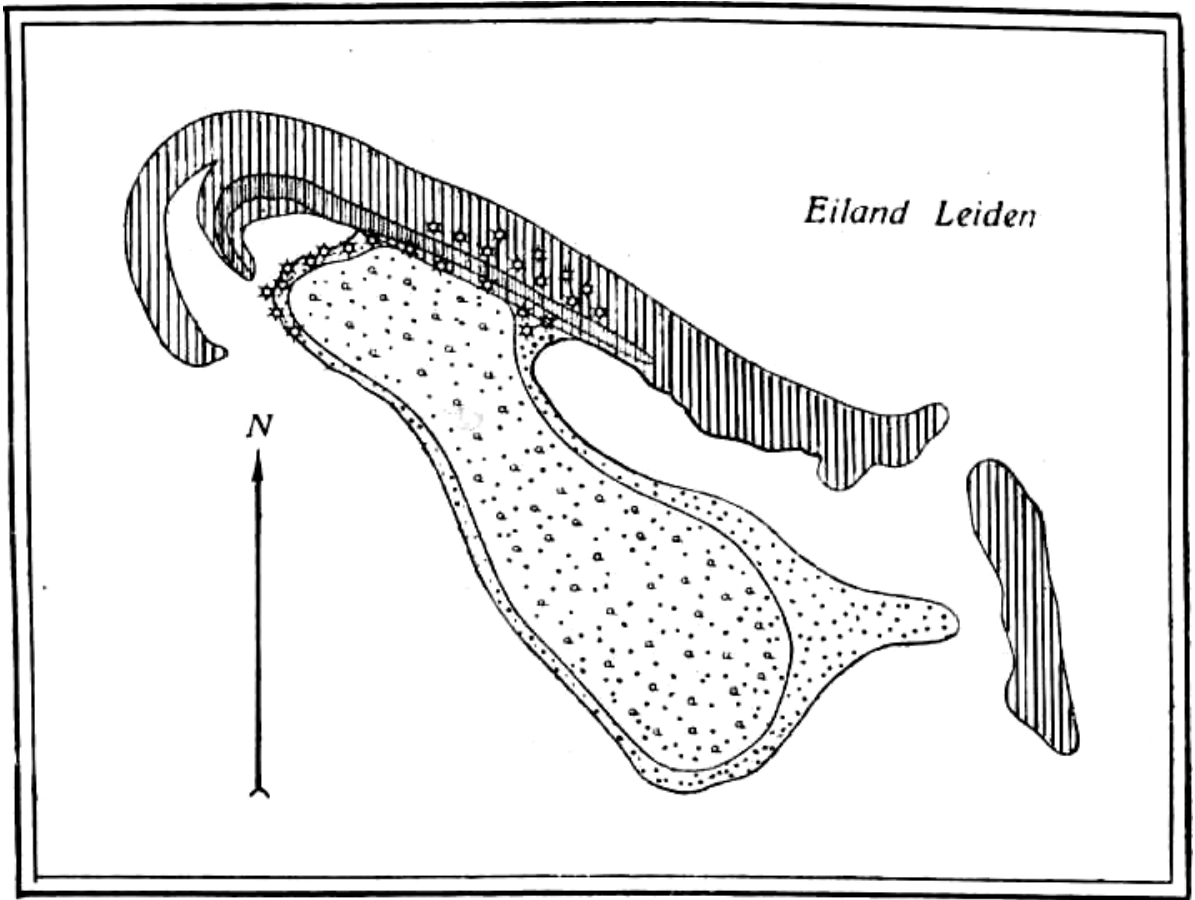

Figure 6. Pulau Nyamuk (UMBGROVE)

In the various sites where UMBGROVE (1940) has carried out his coral studies, he found different constructions of coral reef species and growth forms. Most of his specimens are present in the Leiden Museum and work on the different forms is still continued especially in view of the present day interest in the diversity and variability of the coral species in relation to the complex ecosystem. UMBGROVE (1930) also compared this protected area with the reefs along the Spermonde shelf before the coast of Makassar. In this last area the dominant western trade wind forms the shingle ramparts on the steep reefs. As for the questions arising from the taxonomic study of the different coral species, UMBGROVE (1940) states: "When studying two coral reef regions that are widely seperate, one is struck by the rather great number of identical forms. On the other hand it is difficult to recognize the limits between species and formae due to variability. 
CORAL RESEARCH IN THE INDONESIAN ARCHIPELAGO

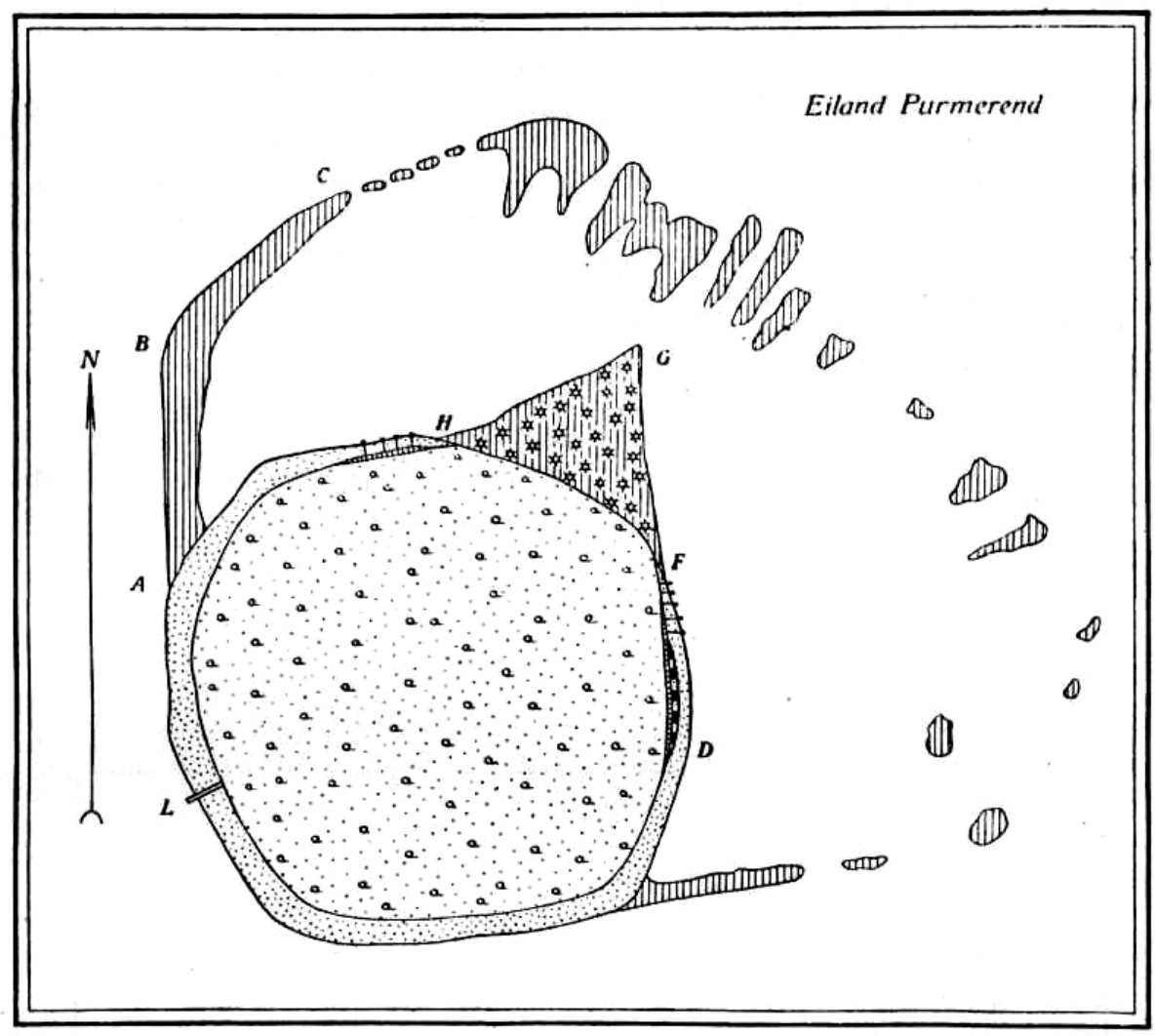

Figure 7. Pulau Sakit (UMBGROVE)

The general statement of UMBGROVE of similar modifications in different species, which we can formulate in a much more detailed way at the moment does not, to the same extent, apply for all coral species. In the hermatypic group of corals, the variability as a result of various ecological conditions, is extensive. The problem of identification of the biological species is very complex in this group. Each coral species with its historical problem, seen as a biological unit, has its ecological problem depending how pliable the species is in respect to intracolonial, intrapopulational, and interpopulational conditions (WIJSMAN- BEST 1974). The intracolonial variability, mainly in branching corals, gives rise to a se- 


\section{MAYA WIJSMAN-BEST}

cond historical problem. The type specimens here can never be representative for the whole of a coral species, because it mostly concerns just a part of the colony. The intra and interpopulational variability, mainly in wide spread, and easily adaptable species, lead to the study of series of corals from different habitats.

Two examples will be treated to illustrate the various problems when one deals with the coral identification. Merulina togianensis UMBGROVE (P1. I; Fig.l) belongs to the family Merulinidae. Merulina is not a common, but a well known genus on the reef. Because of the large intraspecific variability, the species comes in its morphological characters close to Merulina laxa DANA (P1. I; Fig.2). The latter is a ramose Merulina species originally described from the East Indies (Sulu Sea, north of Sulawesi). Only large suits of the two "species" from various localities within a population and also between different populations can settle whether we are dealing here with synonyms or with two biological species. On the other hand several coral students, (WIJSMAN-BEST 1976) have already mentioned the resemblance of some parts of a Merulina laxa colony to the species Hydrophora rigida DANA, (originally described by DANA as a Merulina) (P1. I; Fig.3). The type specimens in the U.S.N.M. (Washington D.C.) are very much alike, but in both cases they are just parts of a colony. This problem has not as yet been solved, historically it cannot be solved and ecologically the various types of variability (intracolonial, intrapopulational, and interpopulational) have to be studied.

Another example is the one of Montastrea curta DANA (P1. II; Fig. 1) belonging to the extra tentacular Faviidae (Montastreinae). This is a common reef coral occurring throughout the Indo-Pacific. In literature it is, to my opinion, confused with Montastrea annuligera MILNE EDWARDS \& HAIME, (WiJSMAN-BEST 1977) (Pl. II; Fig.3). Historically there is no problem. They are both well described by the authors and the types are very representative for the species. Also intracolonially or intrapopulationally there is a distinct seperation; only in at random sampled material, the interpopulational variability shows overlap. M. annuligera occurs more often in shallow water, while $M$. curta has a more wide spread distribution. Another result from my horizontal and vertical distribution studies of the Montastrea species is a distinction of two ecomorphs within Montastrea curta, one with larger corallites, and the other with smaller corallites. In an at random sampled collection of Montastrea species, this smaller ecomorph of $M$. curta (Pl. II; Fig.2) makes the confusion with $M$. annuligera understandable. The same has been observed in the Atlantic coral region, where also two species of the genus Montastrea do occur: Montastrea cavernosa LINNAEUs and Montastrea annularis (ELLis \& SOLANDER). M. cavernosa, the one with the larger corallites, also occurs in a broader range of biotopes and has two ecomorphs than 


\section{CORAL RESEARCH IN THE INDONESIAN ARCHIPELAGO}

M. annularis with smaller corallites. This similar situation can be regarded as a case of parallel evolution. This stresses the fact that we are dealing here with two valid biological species: $M$. curta and $M$. annuligera. When we add some zoogeographical data to this discussion we find that M.curta is the predominant species in the Indonesian Archipelago, Great Barrier Reef, and New Caledonia. M. annuligera is rarer, but is the dominant Montastrea species in the Western Indian Ocean (Mascarenes, Madagascar). This last remark shows the necessity for more study of the zoogeographical variation and distribution in addition to a general need for more ecological oriented research in coral reef studies.

\section{CONCLUSIONS}

Summarizing, it can be stated that of many coral reef problems we are still sorting out the balance between the different approaches by gathering more data (historical, ecological, zoogeographical, etc.)

Indonesia is one of the ideal places for coral research, because of the great variety of reef biotopes we find in this archipelago.

All though more facilities have to be created before the different strategies for coral study can be applied, the Rumphius expeditions I and II are good start (SUKARNO 1974) of a combined further attack of this ecosystem.

Scientifically coral reefs are still insufficiently understood and yet of so vital importance for many Indonesians who earn their living on the coral islands, while on the other hand there is nowadays a serious danger of overexploitation and deterioration of the reefs as a result.

\section{REFERENCES}

BOSCHMA, H. 1948. The species problem in Millepora. Zool. Verh. $1: 115$.

MOLENGRAAFF, G.A.F. 1930. The coral reefs in the Indonesian Archipelago and their distribution and mode of development. Fourth Pac. Sci Congr. IIA : 55-89.

NIERMEYER, J.F. 1911. Barriere riffen en atollen in the Oost-Indische Archipel. Tijdschr. Kon. Ned. Aardr. Gen 2 (27): 877-894.

SUKARNO 1974. The Scleractinian corals of the Rumphius Expedition I in: Report on Rumphius Expedition I. Oseanologi di Indonesia : 1 : 13 - 15.

UMBGROVE, J.H.F. 1928., De koraalriffen in de Baai van Batavia. Dienst v.d mijnbouw in Ned. Ind. Wetensch. Meded. 7: 1-62

1929. De koraalriffen der Duizend eilanden (Java zee). (The coral reefs of the Thousand Islands (Jawa Sea). Dienst v.d. mijnbouw in Ned. Ind. Wetensch. Meded. 12: $1-47$.

---- 1930. De koraalriffen van den Spermonde archipel, S. Celebes. Leidsche. Geol. Meded. III. 5. 2: 227-247. 


\section{MAYA WIJSMAN-BEST}

1940: Madreporaria from the Togian reefs (Gulf of Tomini, N. Celebes) Zool. Meded.22: 265-310.

VERWEY, J. 1931. Coral reef studies. 2. The depth of coral reefs in relation to their oxygen consumption and the penetration of light in the water. Treubia, 13 (z) : 169-198

WIJSMAN-BEST, M. 1974 Habitat induced modification of reef corals (Faviidae) and its consequences for taxonomy. Proc. Sec. Int. Coral Reef Symp. 2. Great Barrier Reef Comm.: 217-228.

1976. Biological results of the Snellius Expedition XXVII.Faviidae collected by the Snellius expedition. II. The genera Favites, Goniastrea, Platygyra, Oulophyllia, Leptoria, Hydnophora, and Caulastrea. Zool Meded 50.4 : 45-62.

1977. Indo-Pacific coral species belonging to the subfamily Montastreinae Vaughan \& Wells, 1943 (Scleractinea-Coelenterata) I. The genera Montastrea and Plesiastrea. Zool Meded. (in press). 
CORAL RESEARCH IN THE INDONESIAN ARCHIPELAGO

PLATE I
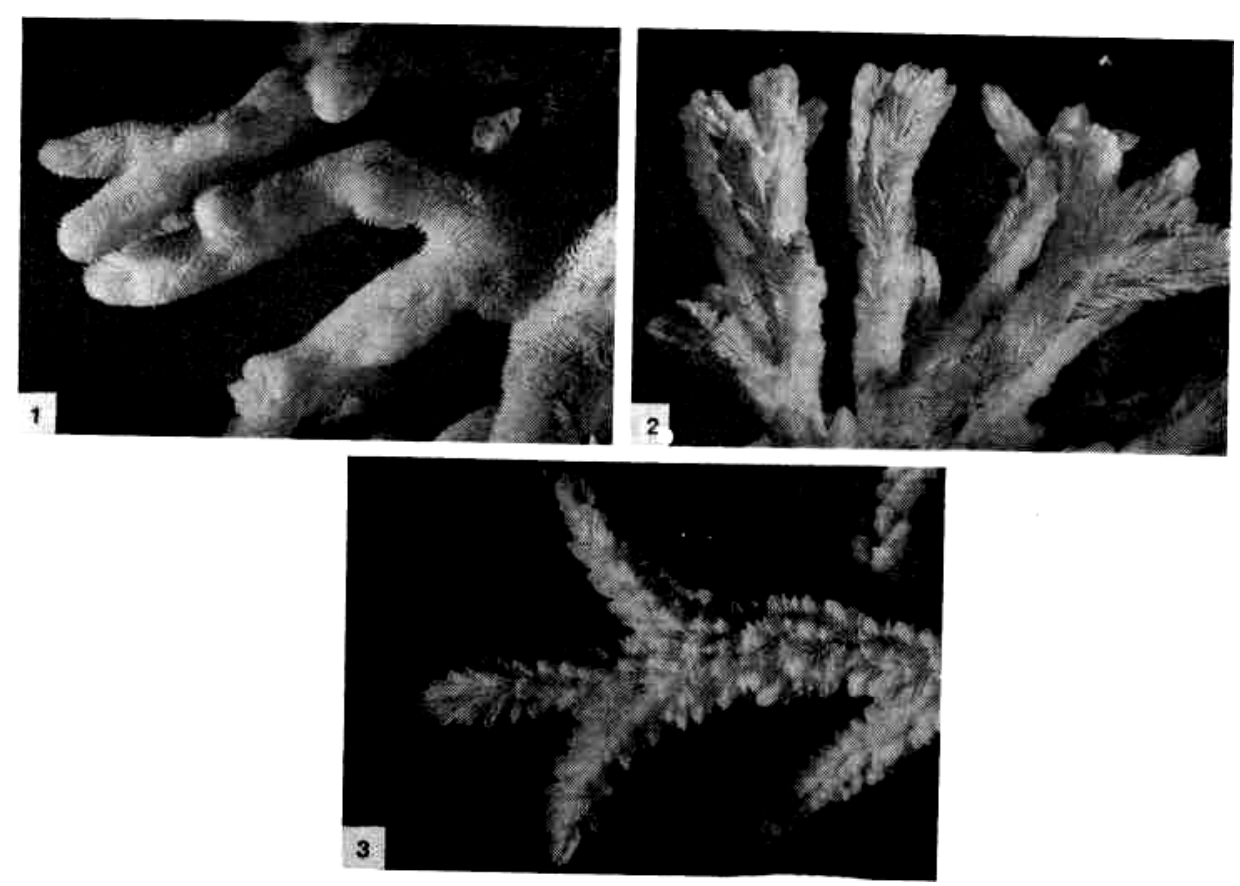

Figure 1. Merulina togianensis UMBGROVE R.M.N.H. Coel 9794 from Togian Islander Celebes.

Figure 2. Mendina laxa DANA R.M.N.H. Coel 9785 from Ambon

Figure 3. Hydnophora rigida DANA R.M.N.H. Coel 9645 from Togian Isl. Celebes. 
MAYA WIJSMAN-BEST

PLATE II
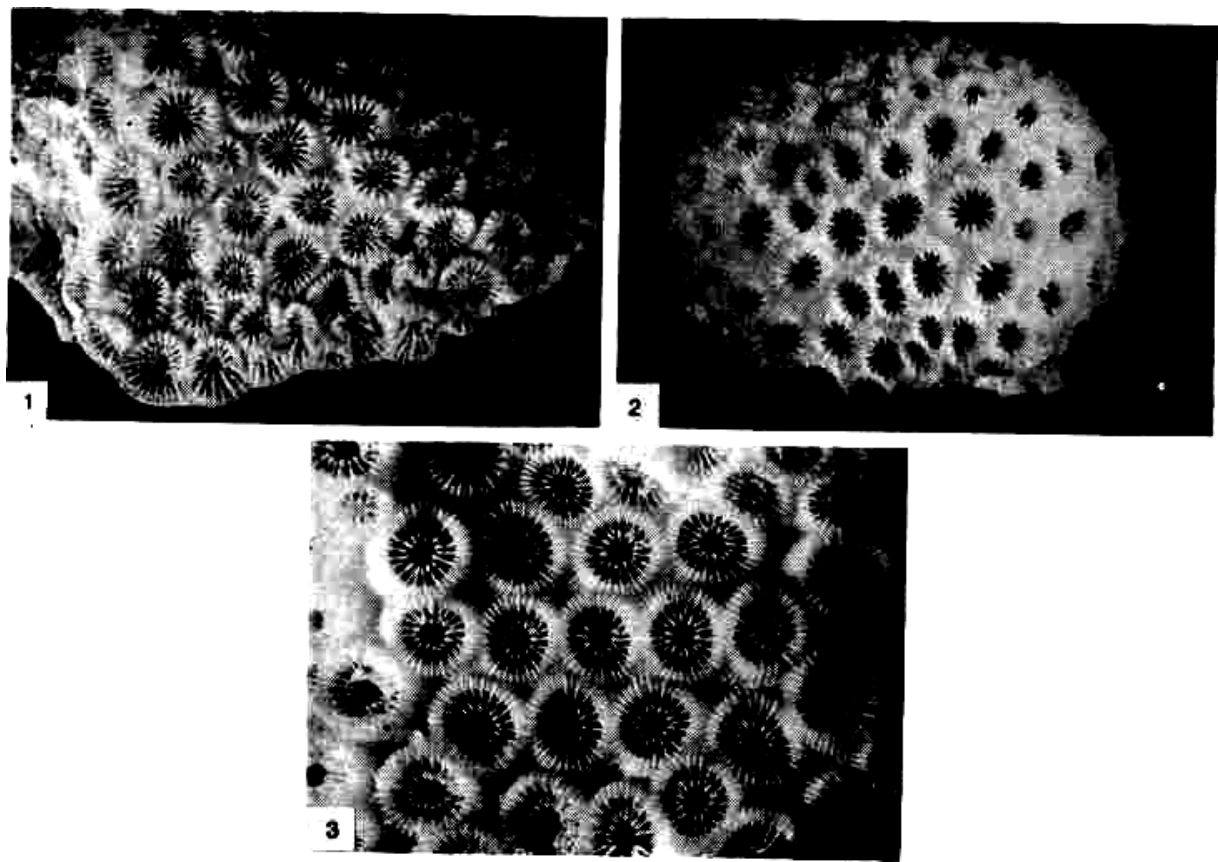

Figure 1. Montastrea curta DANA R.M.N.H. Coel 9895 from Togian Islands Celebes.

Figure 2. Montastrea curta DANA R.M.N.H. Coel 10713 from Heron Island, Great Barrier Reef.

Figure 3. Montastrea annuligera MILNE-EDWARDS \& HAIME R.M.N.H. Coel 10713 from Heron Island. Great Barrier Reef. 